ENTREPRENEURSHIP AND SUSTAINABILITY ISSUES

ISSN 2345-0282 (online) http://jssidoi.org/jesi/

2019 Volume 6 Number 4 (June)

http://doi.org/10.9770/jesi.2019.6.4(38)

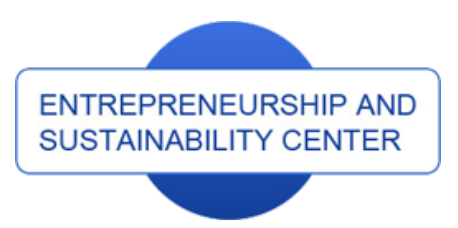

Publisher

http://jssidoi.org/esc/home

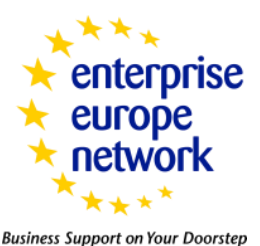

Business Support on Your Doorstep

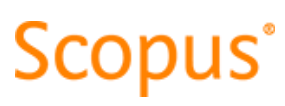

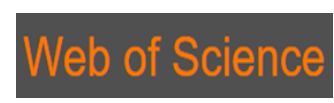

Clarivate

Analytics

\title{
ENTREPRENEURSHIP AT THE LABOUR MARKET: A CASE OF PRECARIAT AND INFORMAL EMPLOYMENT*
}

\author{
Vyacheslav Volchik ${ }^{1}$, Elena Maslyukova ${ }^{2}$ \\ 1,2 Southern Federal University, Bolshaya Sadovaya str. 105, 344006, Rostov-on-Don, Russian Federation \\ E-mails.1volchik@sfedu.ru, ${ }^{2}$ maslyukova@sfedu.ru
}

Received 13 April 2019; accepted 15 May 2019; published 03 June 2019

\begin{abstract}
The concept of precariat is becoming the increasingly important subject of interdisciplinary research that involves both qualitative and quantitative approaches. The formation of the precariat is associated with the neoliberal reforms carried out in the last decades, as well as significant institutional and technological changes. The process of precarisation is accompanied by an increase in insecurity, instability, and flexibility, which is most characteristic of informal and precarious work. Our paper analyzes the relationship between informal employment as a proxy precariat and unemployment rates, industrial production index and real wages using the structural VAR approach for monthly data in the period 2010-2018. The relationship between the variables is checked by imposing restrictions on the recursive scheme (Cholesky identification) as well as the recursive identification scheme (Cholesky decomposition) in the SVAR model. Our analysis of the impulse response caused by the positive shock of informal employment confirmed that in the short term, the increase in the share of people employed in the informal sector causes, above all, a decline in real wages. There are weak responses from the industrial production index, which leads to the conclusion about the leveling effect of institutions and institutions. In addition, the paper employs the process of modeling the development of informal employment using the ARIMA model. Our results showing the trends in the development of informal employment demonstrate the existence of cyclical resilience which negatively affects economic development and requires structural reforms.
\end{abstract}

Keywords: precariat; entrepreneurship; informal employment; labour marke; non-standard employment

Reference to this paper should be made as follows: Volchik, V.; Maslyukova, E. 2019. Entrepreneurship at the labour market: a case of precariat and informal employment, Entrepreneurship and Sustainability Issues 6(4): 2095-2109. http://doi.org/10.9770/ jesi.2019.6.4(38)

JEL Classifications: O15, O43, J08

Additional disciplines: structural VAR model; ARIMA; institutional economics; structural change, technological change

\section{Introduction}

The Great Recession which affected most countries in the world to some extent had a significant impact on the Russian economy, which, along with continuing economic sanctions, largely contributes to its depressive state. However, despite some institutional features, the processes taking place on the Russian labor market are in many

\footnotetext{
* This publication has been prepared in the framework of the project funded by the Russian Foundation for Basic Research (project № 19-010-00651) “University graduates as a new precariat”.
} 


\section{ENTREPRENEURSHIP AND SUSTAINABILITY ISSUES}

ISSN 2345-0282 (online) http://jssidoi.org/jesi/

2019 Volume 6 Number 4 (March)

http://doi.org/10.9770/jesi.2019.6.4(38)

ways similar to the European trends in terms of increasing instability, informality, and the flexibility of social and labor relations (Abbot et al., 2006; Stojanov et al. 2011; Jandová, 2012; Janda et al., 2013; Jiroudková et al., 2015; Abrhám et al., 2015a, Abrhám et al., 2015b; Ćábelková et al. 2015; Strielkowski et al. 2016; Bilan, Strielkowski, 2016; or Niño-Amézquita et al., 2017; Lialina, 2019; Prakash, Garg, 2019). These processes contribute to the spread of unsustainable principles that often violate the labor rights of an employee in the field of labor remuneration and the organization of working time. The current state of the Russian labor market is characterized by various forms of asymmetry in the structure of employment, wages and labor productivity, uneven distribution of income, social vulnerability of the poor, high unemployment which gives rise to asymmetric processes of adaptation to changing market conditions.

Many people have ideas about the labour market that are shaped up by various kinds of discourses. Moreover, discourses that are formed in academic circles are very closely intertwined with discourses associated with the development of educational and economic policies (Strielkowski and Sanderson, 2013; Strielkowski and Weyskrabova, 2014; Höschle et al., 2015). From the point of view of academic discourse, the formation and satisfaction of the demand for highly educated labour depends on market, institutional, technological and other factors, depending on the scientific field in which a particular problem is analysed (Abe et al., 2015).

Over the past hundred years we are witnessing the acceleration of technological and institutional changes that have been happening in the modern world. Moreover, in terms of information technology, the speed of such changes becomes avalanche-like. Understanding the process of precarization of employment is important primarily in terms of the formation of scientific concepts and ideas (Volchik and Maslyukova, 2018) which might serve as the basis for the implementation of economic policies aimed at smoothing out acute social contradictions and forming the basis for balanced and sustainable development of people employed in new and traditional industries economy (Kalyugina et al., 2015; Kalyugina et al., 2018).

In today's world, the formation of precariat occurs under conditions when erosion of the institution of permanent employment occurs. The weakening of job security is widespread in the modern world and is associated with both technological and institutional changes, which can lead to the simultaneous coexistence of full and temporary employment within the same professional groups and sectors of the economy (Čajka et al., 2014; Lazar and Sanchez, 2019).

Technological and institutional changes inevitably lead to the formation of new conditions of employment. Perhaps we are currently witnessing a new "great transformation" (Polanyi, 1957), which will radically change the nature of market interactions, particularly in the labor market. Therefore, the widespread non-standard employment, including various forms of part-time and temporary employment (Choonara, 2019, p. 6), can be viewed in the context of the evolution of the entire capitalist employment system.

Institutional changes in modern developed and developing capitalist economies are closely related to cumulative processes of technological change. The development of information and digital technologies is associated with the problem of evolutionary complexity and adaptive behavior of an economy (Arthur, 1994; Arthur, 1999; and Arthur, 2014). The development of the precariat can also be viewed in the context of the formation of behavioral patterns as an adaptation to institutional and technological changes, as well as to the ongoing state economic policy. Nevertheless, studies of the precariat are beyond the scope of economic issues per se, and therefore ethical and social values matter (Colander, 2014). This becomes especially relevant when one analyses institutions and regulatory mechanisms in contexts of sustainability and welfare in a complex adaptive system. Therefore, it seems that the evolution of institutions and regulatory measures can be viewed through the prism of smoothing dangerous tensions in social, political, and economic contexts. 


\section{ENTREPRENEURSHIP AND SUSTAINABILITY ISSUES}

ISSN 2345-0282 (online) http://jssidoi.org/jesi/

2019 Volume 6 Number 4 (March)

http://doi.org/10.9770/jesi.2019.6.4(38)

\section{Labour market, employment, and precariat}

In the modern world of increasing returns and complexity, competitive advantages are gained by those activities that can best adapt the progress of technologies to their production processes and products. Therefore, the development of information technology, which is associated with the formation of new forms of often unstable employment, can be considered as one of the objective reasons for the formation of the precariat (Mramornova et al., 2019, p. 518). The forms of employment in the free earnings economy (gig economy) are becoming more widespread. In such conditions, there is a redistribution of risk from the state and employers to ordinary citizens engaged in the economy of free earnings (Thelen, 2019, p. 2). These processes can be considered in connection with changes in the institutional regulation of employment. Starting from the middle of the 19th century, the emergence of labor contracts and relevant legislation allowed us to withdraw from the regulation of labor relations on the basis of civil law contracts (Ferguson, 2013). The return to the elements of civil-law regulation of employment can also be viewed as one of the factors of modern precarious work of employment.

The formation of the precariat takes place under the conditions of a tough struggle among intellectual currents, which, going beyond the limits of academic discussions, become instruments for economic policy. Labor market flexibility is seen as a factor in the development of market relations, which, according to neoliberal theories, should affect the efficiency of the use of labor resources. However, labor market flexibility is associated not only with the new needs of workers on a free schedule, but also with the market power of employers (Shammas, 2018, p. 415). Neoliberal economic policies, which are developed under the banner of increased efficiency, in practice are often associated with increased bureaucratic oppression (Graeber, 2015), formalism and control (Strielkowski, 2017; Volchik, 2018), which can cause drift towards informal and partial employment. The processes of globalization and migration associated with it may also be one of the actors of precariationalization (Bernards, 2017), which in turn is associated with government policies aimed at protecting the internal labor market.

Hyper-individualization of workers who, for example, are engaged in freelancing in the academic field (Izharuddin, 2018) can serve as another side of precariatism. The decline of the trade union movement leads to the atomization of workers and adversely affects the ability to jointly defend their rights. Although in some cases strong trade unions may pursue a paternalistic policy towards the unemployed or informally employed, which in turn may lead to ambiguous consequences (Paret, 2018).

Hyper-individualization can be viewed as a continuation of the marketization of professional activity in the digital economy, as well as the spread of outsourcing as a source of precarious work (Siegmann and Schiphorst, 2016, pp 116-117). Depending on the particular institutional environment in various sectors of the economy, precarious employment increases the risk of crowding out workers with a legal and protected status into the sphere of informal employment. Sure? There are some differences primarily in the genesis of informal and non-standard employment, but both of these forms of employment are associated with insecurity and labor insecurity, which allows them to be regarded as forms of precariat (Siegmann and Schiphorst, 2016, p. 115).

The precariate includes groups of the population that are heterogeneous in their social composition, which makes it impossible to establish exact boundaries. In addition, as noted by Gasiukova et al. (2016): "the conditions for the formation of the Russian precariat were radically different from the conditions for its formation in Western societies".

One of the reasons for precarization of employment is the imbalance between the formation of labor and the demand for it existing in the Russian labor market. These differences lead to inconsistencies between the skill level of workers and the jobs they occupy, and the deterioration of the quantitative and qualitative structure of the labor market. Another reason for precarization of employment is "flexibility of numbers", due to the fact that for a long time it was called "atypical" and "non-standard" form of labor: temporary, part-time employment, 


\section{ENTREPRENEURSHIP AND SUSTAINABILITY ISSUES}

ISSN 2345-0282 (online) http://jssidoi.org/jesi/

2019 Volume 6 Number 4 (March)

http://doi.org/10.9770/jesi.2019.6.4(38)

outsourcing, offshoring, "contract with zero time", forced "unpaid leave", the use of interns (Standing, 2011). In the structure of the precariat, the main groups usually include informal employment, temporary and part-time employment, seasonal and fragmentary (episodic) employment, employment and freelancing, the unemployed, migrant workers, students and interns, and NEET youth (Not in Employment, Education or Training) - young people who do not study, do not work and do not participate in vocational training (Toshchenko, 2018).

From the point of view of changes in the economic environment and structural changes, it is important to study the structural factors of precariousization of employment and to characterize the shocks that lead to changes in the level of precarization of employment. The study of the influence of various macroeconomic shocks on the development of the precariate in Russian society is particularly relevant and important for understanding the causes of unstable employment in the context of adaptation to technological, institutional and economic changes in the labor market.

The aim of our study is an empirical analysis and econometric modeling of the nature of the dynamic relationship between indicators characterizing the level of development of informal employment and the state of the labor market based on the SVAR model. The analysis will allow us to characterize the relationship between the level of economic development, unemployment and informal employment (proxy precariat) in the dynamics.

In Russian conditions, informal employment often complements the official employment, since the level of "white" official wages remains extremely low, except for the capital region. Informal employment is widespread both in areas that require higher education and high qualifications (teachers, doctors), and in the services sector, construction, agriculture, where high qualifications are not required. The excessive state regulation of various industries and the lack of structural reforms are associated with the formation of an institutional environment in which competitive market interactions are forced into the shadow and informal economy, which, for example, is typical of Latin American countries (De Soto, 2001).

Most of the studies dealing with the precariat phenomenon use qualitative methods (Choonara, 2019; Volchik et al., 2018) which is due to on the one hand the vagueness of the theoretical framework, and on the other hand the lack of relevant statistical data that can be used in quantitative analysis. However, the precariat issue may be successfully explored in the future as its theoretical framework improves, as well as through the use of proxy variables. In our paper, we explore the precariat in the context of the impact of informal employment on instability and vulnerability in the labor market, which allows us to consider informal employment as a proxy of the precariat.

\section{Data and the empirical model}

For the empirical analysis and modeling of the dynamic relationship between these indicators, we employed the time series empirical model based on the data of monthly dynamics for the period from January 2010 to December 2018. The information statistical array (108 observations) is formed on the basis of data regularly published by the Russian Federal State Statistics Service. The model takes into account the following variables:

informal_emp - the share of people employed in the informal sector (in \% of the total number of employed people) is a proxy variable characterizing the level of development of the precariat. When choosing this variable as a proxy of precariat, we relied on the concept of Standing (2011), who noted that "the shadow economy is exactly the place where most of the precariat is acquired, subjected to exploitation and oppression." "The globalizing open market economy, which is characterized by informal contracts, partial and temporary employment, focus on projects and a myriad of personal services, undoubtedly contributes to shadow labor" (Standing, 2011).

In accordance with the methodology of the Russian Federal State Statistics Service (2019), those employed in the informal sector are persons who during the survey period were employed in at least one of the production units of 
the informal sector, regardless of their employment status and whether this work was for them the main or additional. The criterion for the lack of state registration as a legal entity was adopted as the criterion for determining units of the informal sector.

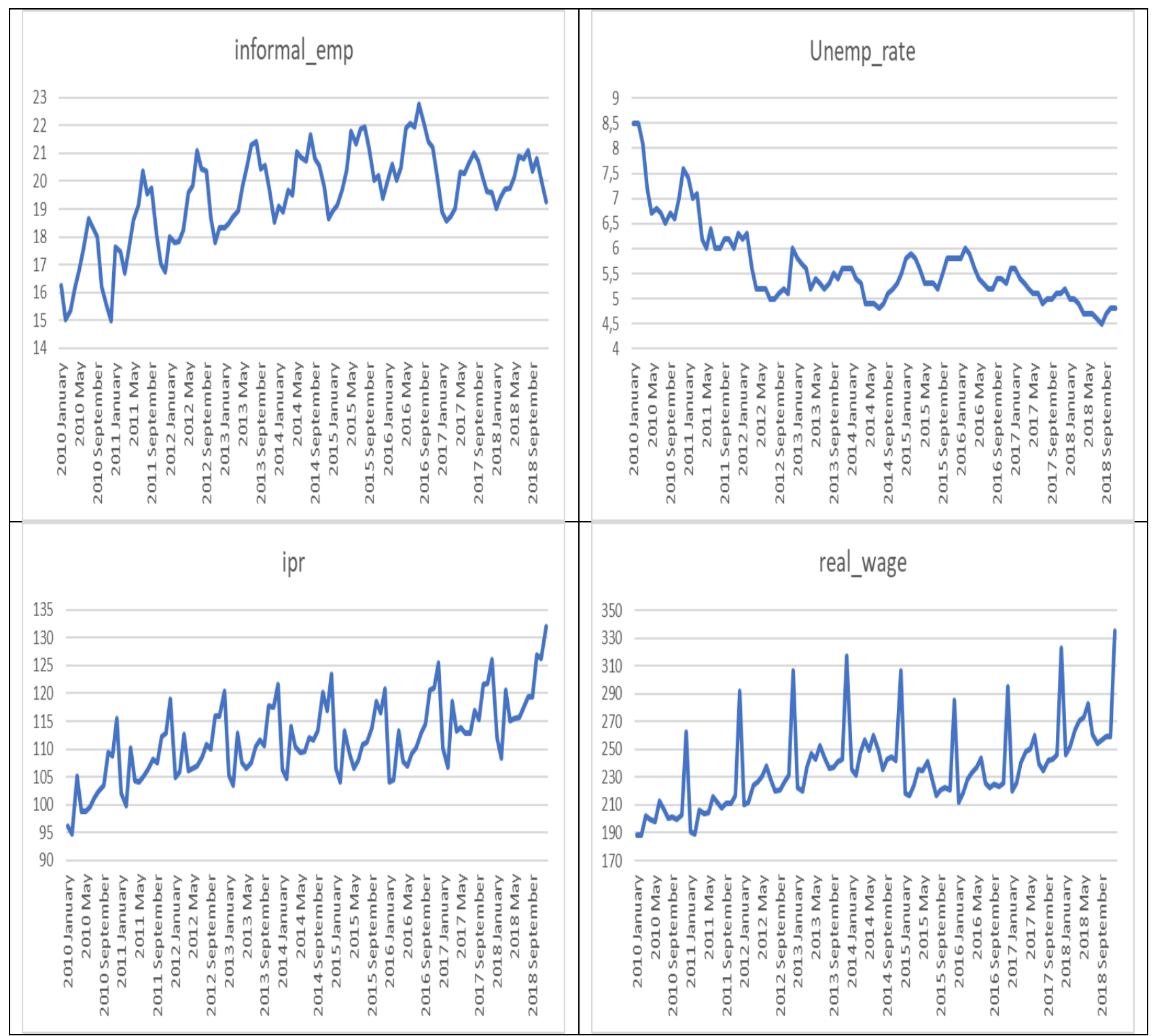

Fig.1. The dynamics of model variables Source: Own results

- unemp_rate - unemployment rate, \%;

- ipr - industrial production index of Higher School of Economics. This variable is used as a proxy for business activity and is calculated on the basis of time series of monthly dynamics in real terms of 272 most important types of products, the production volumes of which constitute a rather significant specific weight in the total industrial output. 


\section{ENTREPRENEURSHIP AND SUSTAINABILITY ISSUES}

ISSN 2345-0282 (online) http://jssidoi.org/jesi/

2019 Volume 6 Number 4 (March)

http://doi.org/10.9770/jesi.2019.6.4(38)

- real_wage - real wages, January $1993=100 \%$.

The index unemp_rate variables that marks the unemployment rate characterizes the efficiency and scale of development of the formal sector of the economy, presenting demand for labor. Thus, Gimpelson and Zudina (2011) note that "reducing unemployment in the region means activating demand and, accordingly, reducing the share of the informal sector". In addition, Tedds and Giles (2002) distinguish two opposite directions of the relationship between unemployment and the informal sector. On the one hand, increasing unemployment may lead to a decline in the informal sector, since it is positively associated with GDP growth rates and ultimately negatively correlates with unemployment (Okun's law). On the other hand, rising unemployment leads to an increase in the number of people employed in the informal sector. During the period under review, there is a tendency for this indicator to decrease.

Indicator ipr - industrial production index - is the most well-known and widely used indicator. In this case, other things being equal, it can be assumed that the higher the level of activity is, the more reason to expect the scale of the development of the formal sector, and vice versa.

The level of real wages (the "real_wage" variable) allows us to present the degree of attractiveness of the formal sector for employees. In this case, other things being equal, it can be assumed that if the level of real wages is higher, the spread of employment in the informal sector of the economy may be lower. The dynamics of indicators is presented in Figure 1 above.

\section{Result and discussions}

Initially, a preliminary statistical test of the time series for the presence of the seasonal component and stationarity was carried out. Based on the results obtained in the graphical analysis of the initial data (Fig. 1), it was concluded that there is a seasonal component in all time series. In addition, none of the considered time series looks stationary. Therefore, before evaluating the VAR model in abbreviated form, we will test the non-stationary nature of the studied series using the Dicky-Fuller test (Augmented Dickey-Fuller test) and KPSS test (the socalled Kwiatkowski-Phillips-Schmidt-Shin test). In the first test, the null hypothesis about the presence of a unit root was tested; in the second test, the null hypothesis was the stationarity of the series. Given the shape of the time series shown in Figure 1, stationarity was tested against a constant and trend. Testing the initial time series indicates the presence of a unit root in the data on the variable informal_emp (the share of employment in the informal sector) and unemp_rate (unemployment rate), while tests of the variables ipr (industrial production index) and real_wage (real wage) gave mixed results, but in terms of the total population, it can be concluded that the series under consideration are not stationary (Table 1).

Table 1. Single root analysis

\begin{tabular}{|c|c|c|}
\hline \multicolumn{1}{|c|}{ Table 1. Single root analysis } \\
\hline Variable & ADF statistics & KPSS test \\
\hline informal_emp & -1.2988 & 0.2263 \\
\hline unemp_rate & -3.9914 & 0.1809 \\
\hline ipr & -1.337 & 0.1314 \\
\hline real_wage & -2.7755 & 0.1232 \\
\hline \multicolumn{3}{|c|}{ Critical values of statistics } \\
\hline $1 \%$ & -3.99 & 0.216 \\
\hline $5 \%$ & -3.43 & 0.146 \\
\hline $10 \%$ & -3.13 & 0.119 \\
\hline
\end{tabular}


After reducing the series to a stationary view by taking seasonal and non-seasonal differences, the VAR (1) model was evaluated in an abbreviated form, the number of lags was determined automatically on the basis of information criteria taking into account the constant (Table 2).

Table 2. The choice of the number of lags in the model

\begin{tabular}{|c|c|c|c|}
\hline $\mathrm{AIC}(\mathrm{n})$ & $\mathrm{HQ}(\mathrm{n})$ & $\mathrm{SC}(\mathrm{n})$ & $\mathrm{FPE}(\mathrm{n})$ \\
\hline 1 & 1 & 1 & 1 \\
\hline \multicolumn{4}{|c|}{ Source: Own results } \\
\hline
\end{tabular}

The results of evaluations of the abbreviated form of the VAR (1) model are given in Appendix 1. From a statistical point of view, the constructed model is adequate. Thus, based on the results of the tests performed, it can be concluded that the model remains missing the problem of autocorrection, as evidenced by the p-values of the portmanto test for 10 counted lags (Table 3 ).

Table 3. Portmanto test for residual autocorrelation

\begin{tabular}{|l|c|c|}
\hline & Chi-squared & p-value \\
\hline Portmanteau Test asymptotic & 154 & 0.28 \\
\hline Portmanteau Test adjusted & 164 & 0.12 \\
\hline Breusch-Godfrey LM test & 79.4 & 0.5 \\
\hline
\end{tabular}

When looking at Figure 2 that follows, one can see that the positive shock of the share of those employed in the informal sector causes, above all, a decline in real wages, while the duration of such a decline is small and is two months.

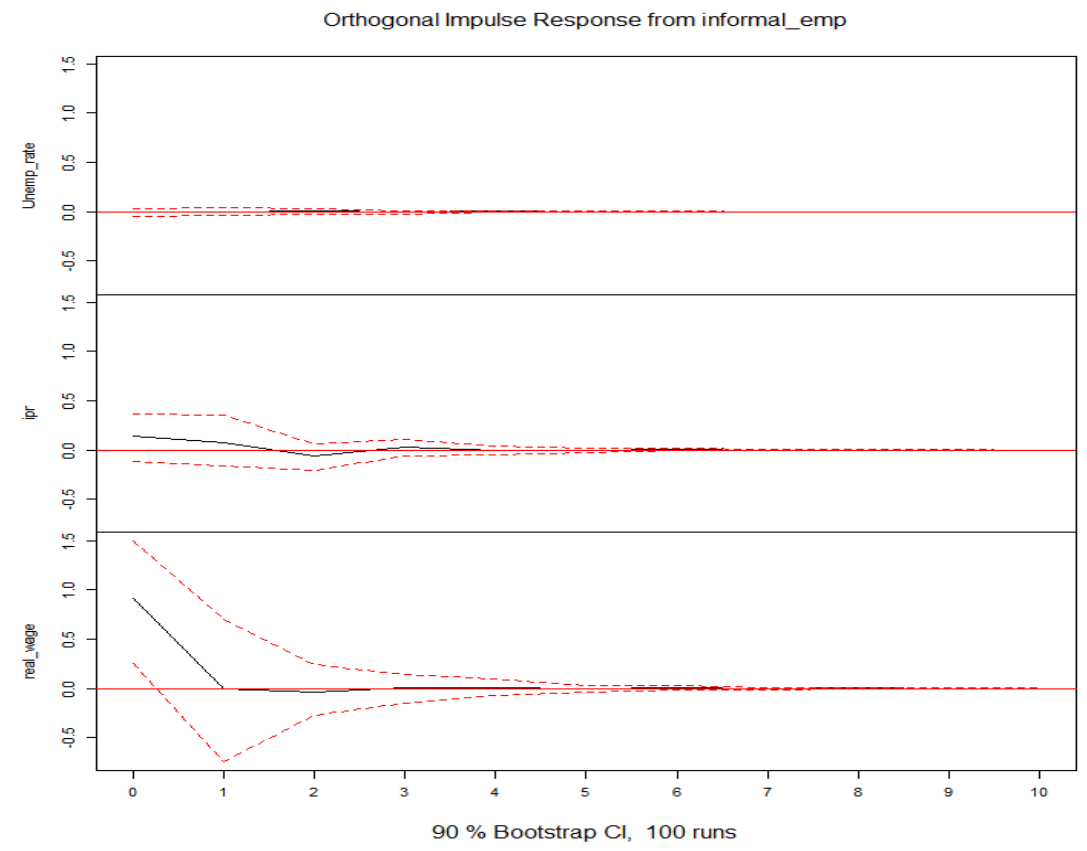

Fig. 2. Functions of impulse responses to the positive shock of the variable informal_emp - the share of people employed in the informal sector Source: Own results

Also, there is a weak reaction of the industrial production index, which is reflected in its slight decrease within two months. 
ENTREPRENEURSHIP AND SUSTAINABILITY ISSUES

ISSN 2345-0282 (online) http://jssidoi.org/jesi/

2019 Volume 6 Number 4 (March)

http://doi.org/10.9770/jesi.2019.6.4(38)

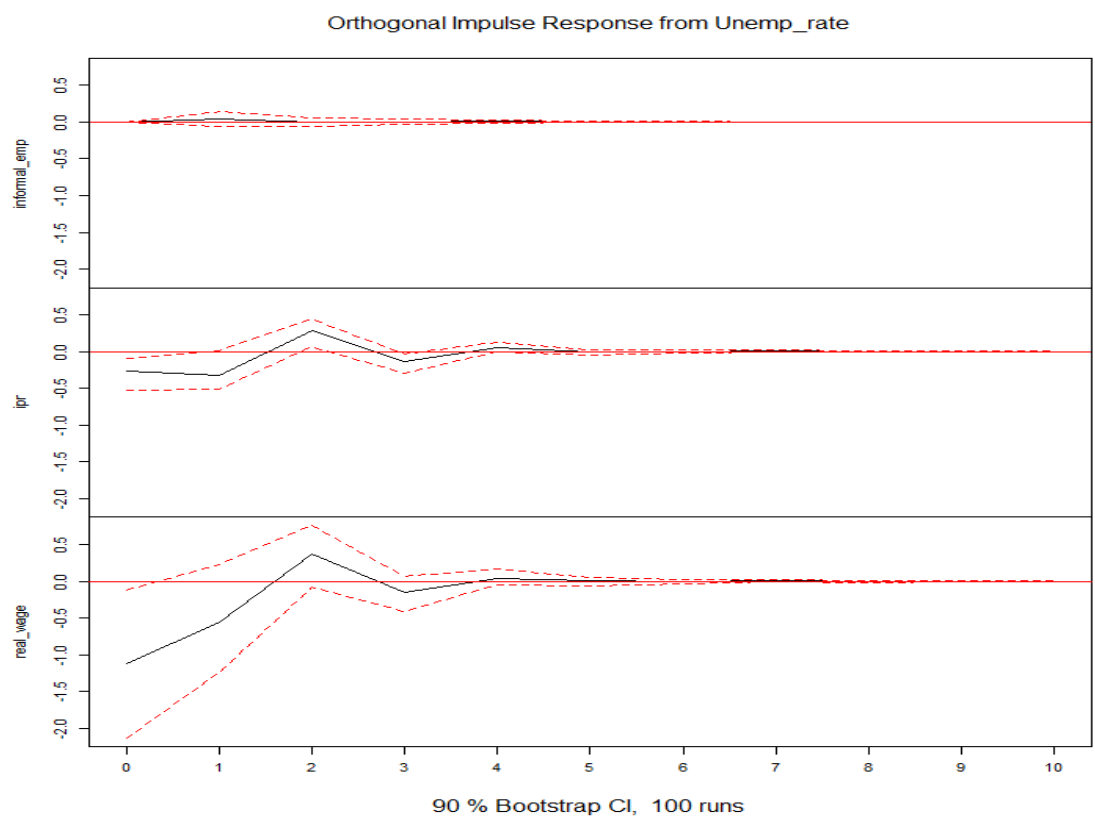

Fig. 3. Impulse response functions for positive shock of the variable unemp_rate - unemployment rate Source: Own results

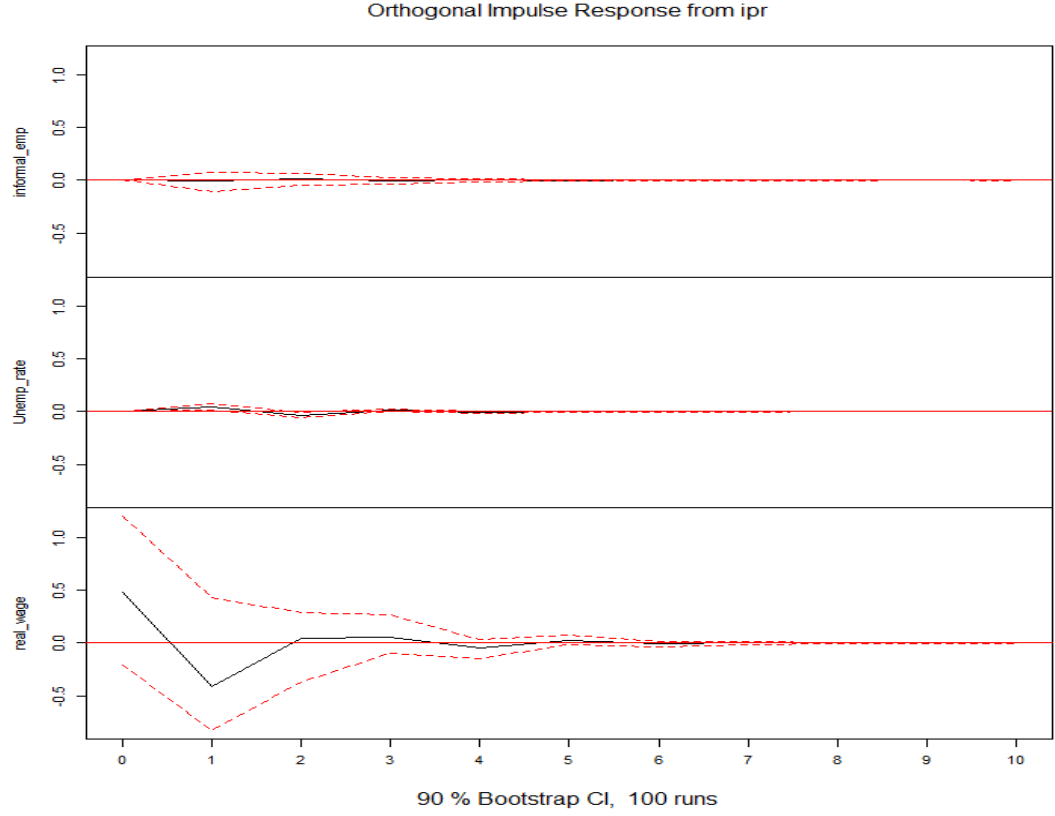

Fig. 4. Functions of impulse responses to positive shock by variable $i p r$ - industrial production index Source: Own results 


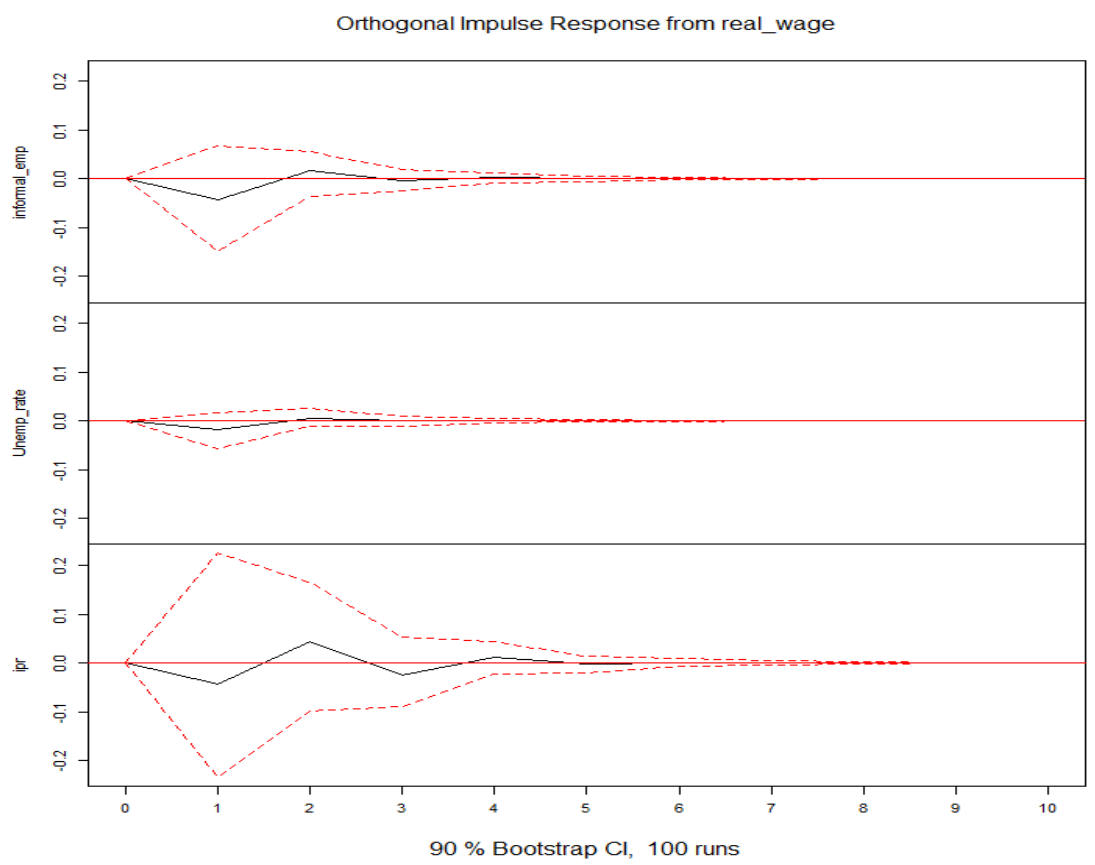

Fig. 5. Impulse response functions for positive shock variable real_wage - real wage Source: Own results

The response of real wages to the shock of unemployment turns out to be positive, and the growth of the industrial production index in response to the positive shock of unemployment has been observed since the second month (Fig. 3). Moreover, the growth of the industrial production index in the short term contributes to a decrease in real wages during the first month, but during the second month real wages return to their previous level (see Figure 4 above). The response of the share of those employed in the informal sector to the shock of real wages turns out to be negative during the first month, while the positive response of the industrial production index is observed starting from the second month (Figure 5 above). The identified short-term effects under the influence of the prevailing institutional structure (environment) of the precariat are leveled over a short time period (length of two months), bringing the indicators to their original values.

As it comes out from Figures 2-5, the confidence interval of the response functions for all variables captures zero, which indicates a statistically insignificant short-term effect of macroeconomic indicators in the period under review, therefore, using ARIMA is proposed to predict informal employment (values of the variable informal_emp - employment in the informal sector). Since the Dickey-Fuller test indicates that the series under study is unsteady, to determine the model parameters, we used automatic generation of a set of optimal model parameters taking into account the seasonality identified earlier and taking into account the order of integration equal to $\mathrm{p}=1$ (see Table 4 that follows).

Table 4. Results of the evaluation of the parameters of ARIMA model $(0,1,1)(0,1,1)$

\begin{tabular}{|l|l|l|}
\hline & ma1 & sma1 \\
\hline Coefficients: & -0.441 & -0.326 \\
\hline s.e. & 0.116 & 0.126 \\
\hline sigma^2 estimated as 0.337: $\log$ likelihood=-72.45 \\
\hline AIC=150.9 AICc=151.2 BIC=158.15 \\
\hline \multicolumn{2}{|c|}{ Source: Own results }
\end{tabular}




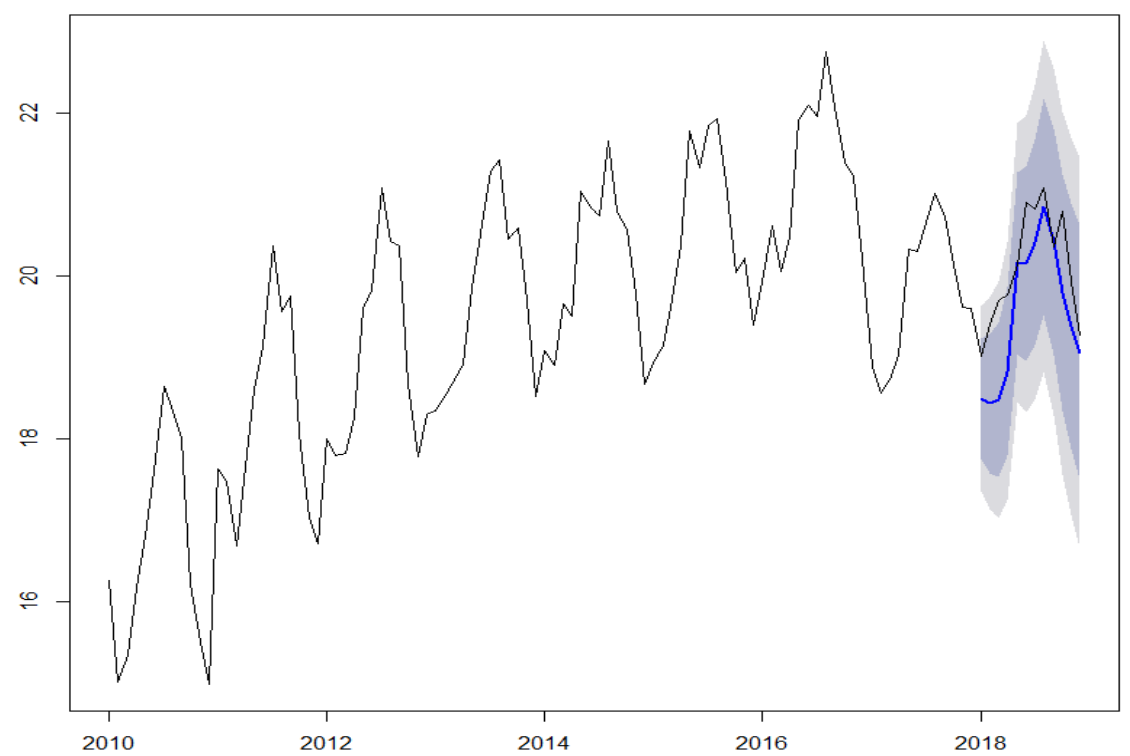

Fig. 6. Prediction of the level of informal employment and confidence intervals.

Source: Own results

The analysis of the obtained model indicates the absence of autocorrelation in the residuals (Box-Ljung test: $\chi$ squared $=23.8, \mathrm{df}=22, \mathrm{p}$-value $=0.36$ ). Therefore, this model can be used for prediction. Testing the model on the so-called quasi-data (that is, building a forecast for the last known levels of time series using the model built without them) showed that the actual values are described quite well by this model: the blue line representing the forecast approaches the original data quite well, the forecast estimates confidence limits are provided: 80\% confidence limits are shaded in dark blue, and 95\% confidence limits are in lighter blue (see Figure 6 above).

The results of our empirical model allow us to conclude that the trends in the development of informal employment demonstrate cyclical resilience, which requires economic policies that promote economic restructuring and the formation of appropriate institutions to protect the rights of workers in traditional and developing industries and spheres.

\section{Conclusions}

Overall, our results demonstrate that in modern Russia precarious employment is associated with the formation of sustainable institutional structures. Institutionalization of precariat leads to the transfer of the properties of institutions: inertia and leveling (stabilizing) effect of economic fluctuations to the situation with informal employment.

The stability of the precariat as a social stratum is indirectly confirmed by data on the stability of informal employment. Moreover, since 2012, informal employment is characterized by a persistently high level with pronounced seasonality. In the Russian context, the institutionalization of the precariat gradually occurs, which is primarily associated with the formation of stable institutions of informal employment. Institutions and institutional structure that promote precaryatisation adversely affect the development prospects of the Russian economy. In the medium term, the social insecurity of the precariat will affect the quality of the human capital of the able-bodied population, which is of particular relevance in the context of rapid technological changes in the information and digital economy. 
All in all, it becomes apparent that strict government regulation aimed at combating informal employment does not give tangible results in the Russian context. One of the directions for state policy in these conditions may be a concentration on creating business infrastructure (including using digital technologies) and deregulation aimed at reducing barriers that have shown their inefficiency. It is also necessary not to reduce, and possibly increase, state funding for programs of various levels of vocational training due to insufficient population demand for them. Therefore, precariat studies are part of the fundamental scientific problem of instability and asymmetry in the labor market, which requires further research on the relationship between the development of the system of education and training and precarious work.

Appendix 1. Results of the evaluation of the reduced VAR model

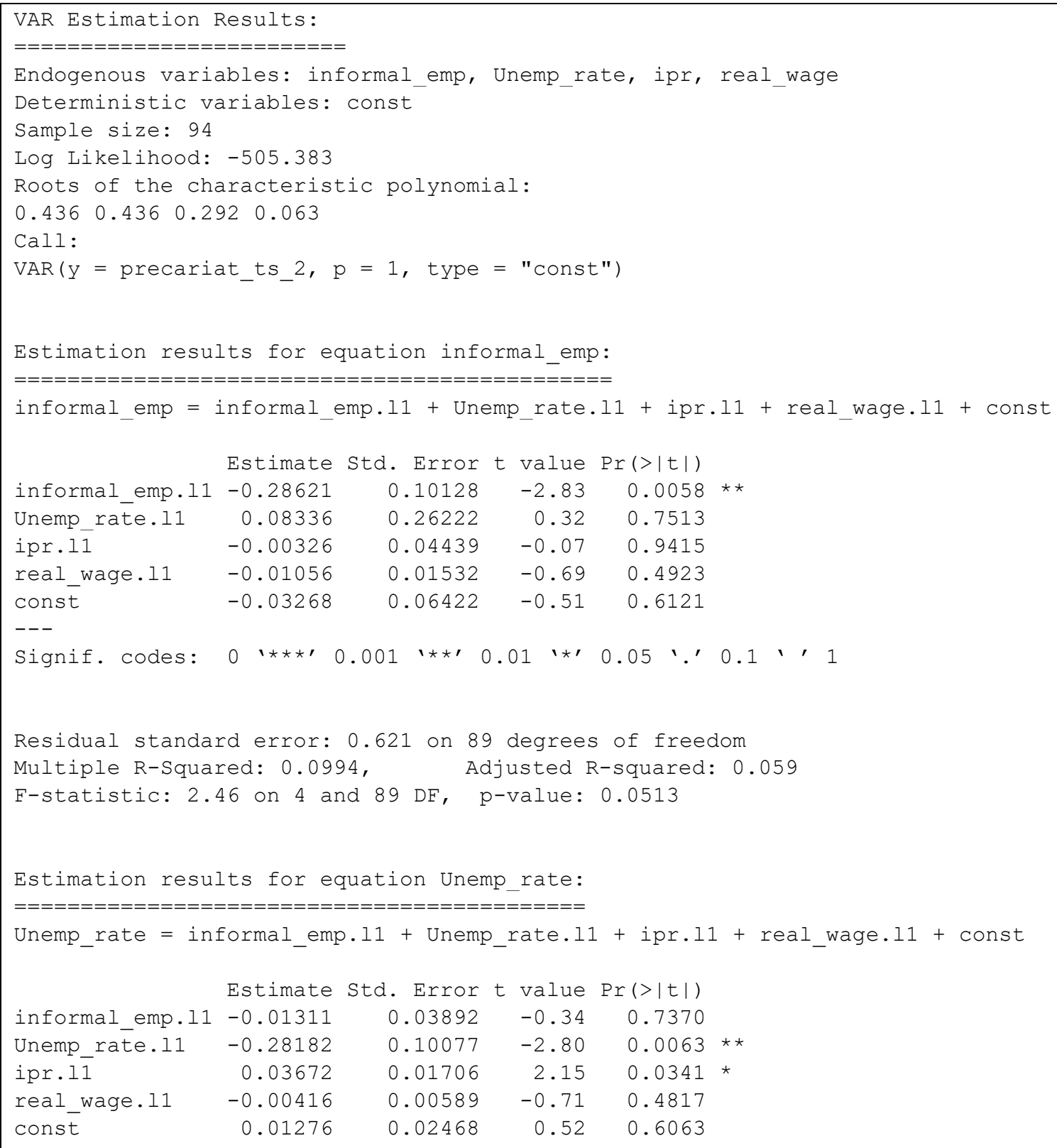




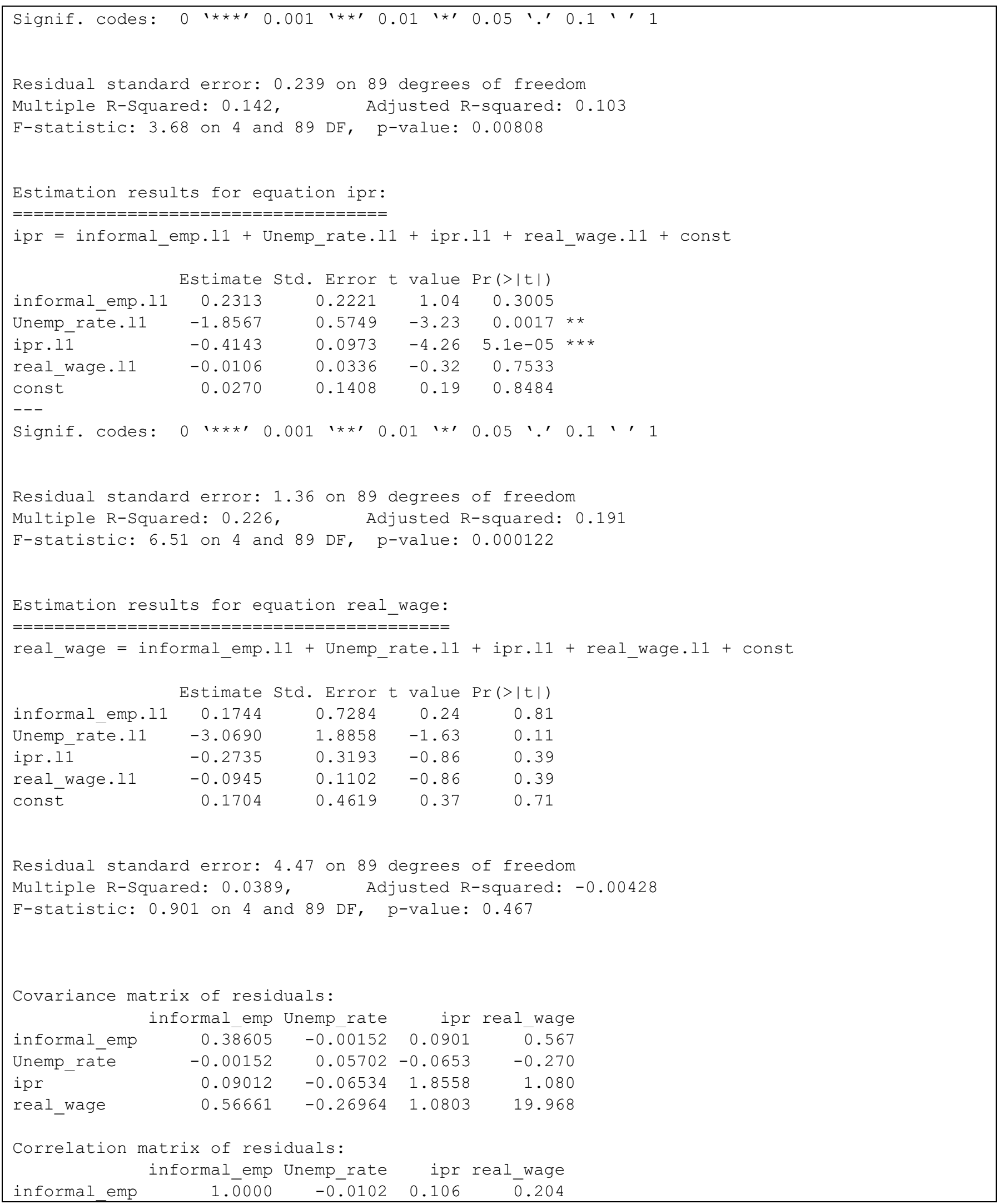




\section{ENTREPRENEURSHIP AND SUSTAINABILITY ISSUES}

ISSN 2345-0282 (online) http://jssidoi.org/jesi/

2019 Volume 6 Number 4 (March)

http://doi.org/10.9770/jesi.2019.6.4(38)

\begin{tabular}{|lrrrr|}
\hline Unemp_rate & -0.0102 & 1.0000 & -0.201 & -0.253 \\
ipr & 0.1065 & -0.2009 & 1.000 & 0.177 \\
real_wage & 0.2041 & -0.2527 & 0.177 & 1.000 \\
\hline
\end{tabular}

Source: Own results

\section{References}

Abbot, C.; Jeong, K.; Allen, S. 2006. The economic motivation for innovation in small construction companies, Construction Innovation 6(3):187-196. https://doi.org/10.1108/14714170610710686

Abe, M.; Troilo, M.; Batsaikhan, O. 2015. Financing small and medium enterprises in Asia and the Pacific, Journal of Entrepreneurship and Public Policy 4(1):2-32. https://doi.org/10.1108/JEPP-07-2012-0036

Abrhám, J.; Bilan, Y.; Krauchenia, A.; Strielkowski, W. 2015a. Planning horizon in labour supply of Belarusian small entrepreneurs, Economic research-Ekonomska istraživanja 28(1):773-787. https://doi.org/10.1080/1331677X.2015.1084238

Abrhám, J.; Strielkowski, W.; Vošta, M.; Šlajs, J. 2015b. Factors that influence the competitiveness of Czech rural small and medium enterprises, Agricultural Economics-Zemedelska Ekonomika 61(10):450-460. doi: https://doi.org/10.17221/63/2015-AGRICECON

Arthur, W. B. 1994. Inductive reasoning and bounded rationality, The American Economic Review 84(2):406-411

Arthur, W. B. 1999. Complexity and the economy, Science 284(5411):107-109. https://doi.org/10.1126/science.284.5411.107

Arthur, W. B. 2014. Complexity and the Economy. $1^{\text {st }}$ edn. Oxford University Press.

Bernards, N. 2017. The global governance of informal economies: the International Labour Organization in East Africa, Third World Quarterly 38(8):1831-1846. https://doi.org/10.1080/01436597.2016.1260448

Bilan, Y.; Strielkowski, W. 2016. Migration in post-transition economies: immigration surplus in Visegrad group countries, International Journal of Trade and Global Markets 9(2):182-196. https://doi.org/10.1504/IJTGM.2016.076310

Choonara, J. 2019. Insecurity, Precarious Work and Labour Markets: Challenging the Orthodoxy. $1^{\text {st }}$ edn. Springer, New York. https://doi.org/10.1007/978-3-030-13330-6

Colander, D. 2014. The economics of influence, Journal of Economic Issues 48(2):485-492. https://doi.org/10.2753/JEI0021-3624480223

Čábelková, I.; Abrhám, J.; Strielkowski, W. 2015. Factors influencing job satisfaction in post-transition economies: the case of the Czech Republic, International Journal of Occupational Safety and Ergonomics 21(4):448-456. https://doi.org/10.1080/10803548.2015.1073007

Čajka, P.; Jaroszewicz, M.; Strielkowski, W. 2014. Migration Incentives and Flows between Belarus, Moldova, Ukraine and the European Union: a Forecasting Model, Economics and Sociology 7(4):11-25. https://doi.org/10.14254/2071-789X.2014/7-4/1

De Soto, H. 2001. The Mystery of Capital: why capitalism triumphs in the West and fails everywhere else, $1^{\text {st }}$ edn. Black Swan, London

Ferguson, N. 2013. The Great Degeneration - How Institutions Fail and Economies Die. $1^{\text {st }}$ edn. Penguin Books, London

Gasiukova E.; Karacharovskiy V.; Yastrebov G. 2016. Unequal Precariousness: On the Origin and Forms of Social Status Instability of Individuals and Groups, Social Sciences and Contemporary World 3:48-63

Gimpelson V.; Zudina A. 2011. Informal Workers in the Russian Economy: Who Are They and How Many? Voprosy Ekonomiki 10:53-76. https://doi.org/10.32609/0042-8736-2011-10-53-76

Graeber, D. 2015. The utopia of rules: On technology, stupidity, and the secret joys of bureaucracy. $1^{\text {st }}$ edn. Melville House Publishing

Höschle, F.; Strielkowski, W.; Tcukanova, O., Welkins, E. 2015. Locational preference and unemployment of Asian-born immigrant in the US metropolises, Geographica Pannonica 19(2): 58-63. https://doi.org/10.5937/GeoPan1502058H

Izharuddin, A.; Lee, L.; Leng, K. S.; Samsurijan, M. S.; Gopal, P. S.; Malek, N. M; Annuar, S. N. S. 2018. Precarious Intellectuals: The Freelance Academic in Malaysian Higher Education, Kajian Malaysia 36(2):1-20. https://doi.org/10.21315/km2018.36.2.1

Janda, K.; Rausser, G.; Strielkowski, W. 2013. Determinants of Profitability of Polish Rural Micro-Enterprises at the Time of EU Accession, Eastern European Countryside 19:177-217. https://doi.org/10.2478/eec-2013-0009 


\section{ENTREPRENEURSHIP AND SUSTAINABILITY ISSUES}

ISSN 2345-0282 (online) http://jssidoi.org/jesi/

2019 Volume 6 Number 4 (March)

http://doi.org/10.9770/jesi.2019.6.4(38)

Jandová, P. 2012. Migration and economic conditions in the EU: a case study of immigrants in Germany. International Economics Letters 1(1):41-48. . https://doi.org/10.24984/iel.2012.1.1.4

Jiroudková, A.; Rovná, L. A.; Strielkowski, W.; Šlosarčík, I. 2015. EU Accession, Transition and Further Integration for the Countries of Central and Eastern Europe, Economics and Sociology 8(2):11-25. http://dx.doi.org/10.14254/2071-789X.2015/8-2/1

Kalyugina, S; Pianov, A.; Tvaronavičienė, M.; Sorokin, G. 2018. Depopulation and external migration as the institutional risks to personnel safety, Journal of institutional studies, 10(4): 125-144. 10.17835/2076-6297.2018.10.4.125-144

Kalyugina, S.; Strielkowski, W.; Ushvitsky, L.; Astachova, E. 2015. Sustainable and secure development: facet of personal financial issues, Journal of Security \& Sustainability Issues 5(2):297-304. https://doi.org/10.9770/jssi.2015.5.2(14)

Lazar, S.; Sanchez, A. 2019. Understanding labour politics in an age of precarity, Dialectical Anthropology 43(1):3-14. https://doi.org/10.1007/s10624-019-09544-7

Lialina, A. 2019. Labor market security in the light of external labor migration: new theoretical findings, Entrepreneurship and Sustainability Issues 6(3): 1105-1125. http://doi.org/10.9770/jesi.2019.6.3(11)

Mramornova, O. V.; Ivanova, N. A.; Sokolova, O. Y.; Musaeva, A. Z.; Abutalimova, S. S. 2018. Social Precarization in Post-Soviet Countries: Common Features and Differences. In: International Conference Project "The future of the Global Financial System: Downfall of Harmony”. $1^{\text {st }}$ edn. Springer, Cham, pp. 516-527. https://doi.org/10.1007/978-3-030-00102-5_54

Niño-Amézquita, J.; Dubrovsky, V.; Jankurová, A. 2017. Innovations and competitiveness in regional development: a comparison of Latin America, Europe, and China, Czech Journal of Social Sciences, Business and Economics 6(1):28-36. https://doi.org/10.24984/cjssbe.2017.6.1.4

Paret, M. 2018. Building Labor Solidarity in Precarious Times: The Danger of Union Paternalism, Labor Studies Journal, 0160449X18814310. https://doi.org/10.1177/0160449X18814310

Polanyi, K. 1957. The Great Transformation: The Political and Economic Origins of Our Time, $1^{\text {st }}$ edn. Boston, N.J.: Beacon Press, 546p.

Prakash, R., Garg, P. 2019. Comparative assessment of HDI with Composite Development Index (CDI), Insights into Regional Development 1(1): 58-76. https://doi.org/10.9770/ird.2019.1.1(5)

Shammas, V. L. 2018. Superfluity and insecurity: Disciplining surplus populations in the Global North, Capital \& Class 42(3):411-418. https://doi.org/10.1177/0309816817738319

Siegmann, K.A., Schiphorst, F. 2016. Understanding the globalizing precariat: From informal sector to precarious work, Progress in Development Studies 16(2):111-123. https://doi.org/10.1177/1464993415623118

Standing, G. 2011. The Precariat: The New Dangerous Class. $1^{\text {st }}$ edn. Bloomsbury Academic Press. https://doi.org/10.5040/9781849664554

Stojanov, R.; Strielkowski, W.; Drbohlav, D. 2011. Labour migration and remittances: current trends in times of economic recession, Geografie 116(4):375-400

Strielkowski, W. 2017. Predatory journals: Beall's List is missed, Nature 544(7651):416. http://doi.org/10.1038/544416b

Strielkowski, W.; Sanderson, M. 2013. Structural channels for Ukrainian labour migration in the Czech Republic, Trames - Journal of the Humanities and Social Sciences 17(3):313-323. https://doi.org/10.3176/tr.2013.3.06

Strielkowski, W.; Tumanyan, Y.; Kalyugina, S. 2016. Labour Market Inclusion of International Protection Applicants and Beneficiaries, Economics and Sociology 9(2):293-302. http://doi.org/10.14254/2071-789X.2016/9-2/20

Strielkowski, W.; Weyskrabova, B. 2014. Ukrainian Labour Migration and Remittances in the Czech Republic. Tijdschrift voor economische en sociale geografie 105(1):30-45. https://doi.org/10.1111/tesg.12052

Tedds, L. M.; Giles, D. E. 2002. Taxes and the Canadian underground economy. Taxes and the Canadian underground economy, Toronto: Canadian Tax Foundation https://www.ctf.ca/ctfweb/en/publications/product_detail.aspx?prod=TP106

Thelen, K. 2019. The American Precariat: US Capitalism in Comparative Perspective, Perspectives on Politics 17(1):5-27. https://doi.org/10.1017/S1537592718003419

Toshchenko Zh.T. 2018. Precariat: from Protoclass to a New Class. Monograph. $1^{\text {st }}$ edn. Institute of Sociology, Russian Academy of Sciences, Russian State University for the Humanities, Moscow: Nauka.

Volchik V.V. 2018. The Rise of Metrics, Terra Economicus 16(4): 6-16. https://doi.org/10.23683/2073-6606-2018-16-4-6-16 


\section{ENTREPRENEURSHIP AND SUSTAINABILITY ISSUES}

ISSN 2345-0282 (online) http://jssidoi.org/jesi/

2019 Volume 6 Number 4 (March)

http://doi.org/10.9770/jesi.2019.6.4(38)

Volchik, V. V.; Maslyukova, E. V. 2018. Narratives, Ideas and Institutions, Terra Economicus 16(2): 150-168. https://doi.org/10.23683/2073-6606-2018-16-2-150-168

Volchik, V.; Klimenko, L.; Posukhova, O. 2018. Socio-economic sustainable development and the precariat: a case study of three Russian cities. Entrepreneurship and Sustainability Issues 6(1):411-428. https://doi.org/10.9770/jesi.2018.6.1(25)

\section{Acknowledgements}

This publication has been prepared in the framework of the project funded by the Russian Foundation for Basic Research (project № 19-010-00651) "University graduates as a new precariat".

Vyacheslav VOLCHIK is the Head of the Department "Economic Theory", and Head of the Laboratory "Institutional Analysis of Economy". Research interests: institutional economics; entrepreneurship and regional development, sustainable development, socioeconomics; precariat; economics of education.

ORCID ID: orcid.org/0000-0002-0027-3442

Elena MASLYUKOVA is the Associate Professor of the Department "Economic cybernetics". Research interests: mathematical and quantitative methods in economics, entrepreneurship and regional development, econometric and statistical methods and methodology, economics of education.

ORCID ID: orcid.org/0000-0002-9918-3040

Copyright (C) 2019 by author(s) and VsI Entrepreneurship and Sustainability Center This work is licensed under the Creative Commons Attribution International License (CC BY). http://creativecommons.org/licenses/by/4.0/

c) (7) Open Access

